\title{
Immobilization of Yarrowia lipolytica for Aroma Production from Castor Oil
}

\author{
Adelaide Braga • Isabel Belo
}

Received: 28 November 2012 / Accepted: 5 February 2013 /

Published online: 19 February 2013

(C) Springer Science+Business Media New York 2013

\begin{abstract}
The main aim of this study was to compare different materials for Y. lipolytica immobilization that could be used in the production of $\gamma$-decalactone (a peach-like aroma) in order to prevent the toxic effect both of the substrate and the aroma upon the cells. Therefore, cells adsorption onto pieces of methyl polymethacrylate and of DupUM ${ }^{\circledR}$ was studied and further used in the biotransformation of castor oil into $\gamma$-decalactone. The highest aroma concentration was obtained with immobilized cells in DupUM ${ }^{\circledR}$, where reconsumption of the aroma by the cells was prevented, contrarily to what happens with free cells. This is a very promising result for $\gamma$-decalactone production, with potential to be used at an industrial level since the use of immobilized cells system will facilitate the conversion of a batch process into a continuous mode keeping high cell density and allowing easier recovery of metabolic products.
\end{abstract}

Keywords $\gamma$-decalactone $\cdot$ DupUM ${ }^{\circledR} \cdot$ Immobilized cells $\cdot$ Methyl polymethacrylate $\cdot$ Yarrowia lipolytica

\section{Introduction}

$\gamma$-Decalactone is commonly used in the flavor industry due to its peach flavor [1]. Previously, it was obtained directly from fruits and by chemical synthesis leading to high product price ( $>$ US\$ $10,000 \mathrm{~kg}^{-1}$ ) but increasing demand for natural flavor compounds by consumers has encouraged food scientists to produce natural $\gamma$-decalactone by microbial processes and with a significant decrease in its price (around US\$ $300 \mathrm{~kg}^{-1}$ ) [2]. However, most of the processes described in the literature report low aroma concentrations rarely reaching values over 4 to $5 \mathrm{gL}^{-1}$ of fermentation broth.

Yarrowia lipolytica can use $\gamma$-decalactone as a carbon source when the substrate is completely consumed [3] resulting in its complete disappearance from the medium after some hours of batch operation. On the other hand, Waché et al. [4] observed that lactones have a toxic effect against the producing cells which results in cell growth inhibition and

\footnotetext{
A. Braga $\cdot$ I. Belo $(\bowtie)$

IBB-Institute for Biotechnology and Bioengineering, Center of Biological Engineering, University of Minho, Campus de Gualtar, 4710-057 Braga, Portugal

e-mail: ibelo@deb.uminho.pt
} 
limitation of the production rate. The decline of cell viability has been shown to be associated with an increase of lactone concentration in culture media during biotransformation [5].

Previous works on $\gamma$-decalactone production describe the use of hydrolyzed castor oil or ricinoleic acid as substrate in order to increase the yields of the process [6, 7]. Lin et al. [8] observed that the addition of ricinoleic acid to the medium increased $\gamma$-decalactone production but resulted in a significant decrease in the population of living cells with the rate of decrease proportional to the increase of ricinoleic acid concentration.

Thus, an alternative technique should be considered to overcome this problem and improve the aroma production. One approach of great interest is the immobilization of viable cells to use in the biotransformation process since, when compared with free cells, immobilized cells exhibit a higher tolerance to toxic compounds (such as the aroma and ricinoleic acid), resulting in higher productivities of the process.

The immobilization of cells by adsorption can be a simple and cheap way for immobilize cells if an appropriate support is found. Moreover, this method is the most suitable for largescale immobilization.

Thus, with the aim of improving the productivity of the aroma production process, the present work reports the study of different methodologies for immobilization of Y. lipolytica cells. Different supports and culture conditions were tested in order to achieve a suitable method for cell immobilization. After selecting the best conditions for cell immobilization, free and immobilized cells were used in the biotransformation of ricinoleic acid (presented as castor oil) into $\gamma$-decalactone.

\section{Experimental Procedures}

\section{Microorganism}

Y. lipolytica strain ATCC20460 was maintained in YPDA medium $\left(10 \mathrm{gL}^{-1}\right.$ yeast extract, $20 \mathrm{gL}^{-1}$ peptone, $20 \mathrm{gL}^{-1}$ glucose, and $20 \mathrm{gL}^{-1}$ agar) at $4{ }^{\circ} \mathrm{C}$.

\section{Cell immobilization-Adsorption}

Methyl polymethacrylate cylinders (C-PMMA) and DupUM ${ }^{\circledR}$ (a thermoplastic support, developed at University of Minho, Portugal [9]) were used as support materials for the cells immobilization.

Yeast cells were pre-grown in 500-mL Erlenmeyer flasks with 200-mL of YPD medium ( $10 \mathrm{gL}^{-1}$ yeast extract, $20 \mathrm{gL}^{-1}$ peptone, and $20 \mathrm{gL}^{-1}$ glucose) at $140 \mathrm{rpm}$ and $27{ }^{\circ} \mathrm{C}$, for $24 \mathrm{~h}$. The influence of different factors (time, cells concentration, $\mathrm{pH}$, and total area of support) in the immobilization of Y. lipolytica cells by adsorption was studied. After the growth phase, the yeast cells were separated from the growth medium by centrifugation $(6,000 \mathrm{rpm}, 5 \mathrm{~min})$ and transferred to the adsorption media (sodium chloride, $10 \mathrm{mM})$ [10]. Different experiments were performed, as described below (Table 1), in order to study the influence of different factors in cell adhesion. Cell suspension was kept in contact with the supports during $48 \mathrm{~h}$ in an orbital shaker at $140 \mathrm{rpm}$ and $27^{\circ} \mathrm{C}$.

The influence of the hydrophobicity of cells in the adsorption process was evaluated by the microbial adhesion to hydrocarbons (MATH) assay. Cells, during the adsorption time, were harvested and washed twice with phosphate buffer $(0.1 \mathrm{M}, \mathrm{pH} 7)$, centrifuged (3,000 rpm, $5 \mathrm{~min}$ ), and re-suspended in the same buffer to an optical density of $600 \mathrm{~nm}$ (OD 600) of approximately $0.7\left(A_{0}\right)$. In a glass tube, one part of this suspension was mixed with six parts of hexadecane. The tube was gently inverted ten times and left until the 
Table 1 Descriptions of different experiments performed for cell immobilization by adsorption, using two different supports of different materials and shape (schematically shown)

\begin{tabular}{|c|c|c|c|c|c|}
\hline Support & $\begin{array}{l}\text { Surface area } \\
\left(\mathrm{m}^{2} \mathrm{~m}^{-3}\right)\end{array}$ & $\begin{array}{l}\text { Medium } \\
\mathrm{pH}\end{array}$ & $\begin{array}{l}\text { Initial cell concentration } \\
\left(\text { cell } \mathrm{mL}^{-1}\right)\end{array}$ & $\begin{array}{l}\text { Cell }_{\text {initial }} / \text { support } \\
\text { area }_{\text {total }}(\text { cell m² }\end{array}$ & $\begin{array}{l}\text { Medium } \\
\text { volume }(\mathrm{mL})\end{array}$ \\
\hline & \multirow[t]{2}{*}{0.95} & 7 & $1.57 \times 10^{8} \pm 1.20 \times 10^{6}$ & $5.2 \times 10^{9} \pm 1.20 \times 10^{6}$ & \multirow[t]{2}{*}{50} \\
\hline & & 9 & & $3.5 \times 10^{9} \pm 1.20 \times 10^{6}$ & \\
\hline
\end{tabular}

\section{C-PMMA}

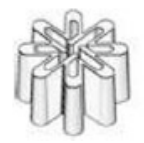

407

$\operatorname{DupUM}^{\circledR}$
9
$5.9 \times 10^{8} \pm 2.56 \times 10^{6}$

$7.4 \times 10^{9} \pm 4.56 \times 10^{6}$

90

$1.1 \times 10^{10} \pm 3.89 \times 10^{6}$

separation of the two phases. Then, $2 \mathrm{~mL}$ of the aqueous phase were removed and the OD 600 (A) was measured [11]. The results are given as percentage of adhesion (Eq. 1):

$$
\% \text { adhesion }=100-\left(100-{ }_{\mathrm{A} / \mathrm{A}_{0}}\right)
$$

\section{Biotransformation Experiments}

In the biotransformation experiments, free and immobilized cells, were used. In the experiments with free cells, cells were pre-grown as described above and were then used to inoculate (to a cellular concentration of $1.2 \times 10^{8}$ cells $\mathrm{mL}^{-1}$ ) a $500-\mathrm{mL}$ Erlenmeyer flask with $200 \mathrm{~mL}$ of YPD medium, which was agitated at $140 \mathrm{rpm}$ and $27^{\circ} \mathrm{C}$, during $24 \mathrm{~h}$, until cultures reached the late-logarithmic growth phase and glucose was completely consumed (confirmed by the DNS method [12]).

In order to increase the availability of the substrate (ricinoleic acid) to the cells for $\gamma$-decalactone production, hydrolyzed castor oil can be used. In this work, the hydrolysis of the oil was promoted by enzymatic action, more specifically by the extracellular lipase Lipozyme TL IM [13].

For castor oil hydrolysis, $10 \mathrm{~g}$ of lipase $(35 \mathrm{U})$ was added to the flask containing the biotransformation medium $\left(30 \mathrm{gL}^{-1}\right.$ castor oil, $6.7 \mathrm{gL}^{-1}$ yeast nitrogen base with amino acids, $2.5 \mathrm{gL}^{-1} \mathrm{NH}_{4} \mathrm{Cl}$, and $3 \mathrm{gL}^{-1}$ Tween 80) and it was incubated at $140 \mathrm{rpm}$ and $27{ }^{\circ} \mathrm{C}$, during $48 \mathrm{~h}$, the time needed to achieve a $95 \%$ hydrolysis [13]). The yeast cells (free and immobilized) were then transferred to the biotransformation medium. Experiments were repeated at least twice and data are presented as the mean and standard deviation of two independent experiments (mean \pm standard deviation).

\section{Analytical Methods}

a) Cell concentration

Free cells concentration was estimated using a Neubauer-improved cell counting chamber.

Immobilized cells concentration was achieved by the difference in the absorbance between the adsorption medium in the absence of the support and in its presence. 
b) Support characterization

Static contact angle measurements were obtained using OCA 20 from Dataphysics to determine the support hydrophobicity. Water contact angle measurements were performed at room temperature using the sessile drop method [14]. The reported angles consist of an average of seven independent measures.

Micrographs of the biocatalysts, after cell adsorption (dried for $24 \mathrm{~h}$ at $60{ }^{\circ} \mathrm{C}$ ), were obtained by scanning electron microscopy (SEM) using a Leica Cambridge S360 microscope. To be examined, samples were fixed on a specimen holder with aluminum tape and then sputtered with gold in a sputter coater under high vacuum condition. Each sample was examined at 1,000-fold magnification.

c) Lactone extraction and analyses

For the quantification of $\gamma$-decalactone, $2 \mathrm{~mL}$ medium samples were removed and their $\mathrm{pH}$ was lowered to 2 with $\mathrm{HCl}$. The extraction of the aromatic compound was performed with $2 \mathrm{~mL}$ diethyl ether by 60 gentle hand shakings, after addition of $\gamma$-undecalactone, as internal standard. After the complete separation of the liquid phases, the ether phase was analyzed by gas chromatography (Varian 3800 instrument, Varian Inc., USA), with a TRWAX capillary column (30 $\mathrm{m} \times 0.32 \mathrm{~mm} \times 0.25 \mu \mathrm{m}$, Teknokroma, Spain) with He as a carrier gas. The temperatures of the split injector and the detector were set to 250 and $300{ }^{\circ} \mathrm{C}$, respectively. The oven temperature was programmed to increase from 60 to $145^{\circ} \mathrm{C}$ at a rate of $5^{\circ} \mathrm{Cmin}^{-1}$ and then to $180{ }^{\circ} \mathrm{C}$ at a rate of $2{ }^{\circ} \mathrm{Cmin}^{-1}$ [15]. Data were analyzed using the acquisition and integration software Star Chromatography Workstation v. 6.30 (Varian Inc., USA).

\section{Results and Discussion}

\section{Cell Immobilization by Adsorption}

The adsorption phenomenon is based on electrostatic interactions (van der Walls forces) between the charged support and microbial cells; therefore, their zeta potential plays a significant role in cell-support interactions. Along with the charge on the cell surface, the composition of the cell wall, the support and its properties will also play a relevant role, influencing the cell-support interaction [16].

For a good immobilization, it is important to achieve a high amount of cells adhered to the support surface. So, the influence of different factors (time, cells concentration, $\mathrm{pH}$ of the medium, and total area of support) in the adsorption of Y. lipolytica cells to different supports was studied.

The $\mathrm{pH}$ of the adhesion medium is an important factor in the adsorption of cells to surfaces. Since an extreme $\mathrm{pH}$ value $(<4$ or $>9)$ inhibits microbial growth and biosynthesis of extracellular polymers necessary for biofilm formation [17], the $\mathrm{pH}$ values studied were 7 (neutral) and 9. Figure 1 shows that $\mathrm{pH}$ was an important variable in this study, since it was observed a decrease in the number of cells adhered, for the higher amount of support area used, when the $\mathrm{pH}$ of the medium changed from 9 to 7 . This effect was not significantly detected for the lower cells adhesion obtained with the lower support area.

Several procedures of cell adsorption based on $\mathrm{pH}$ dependence are reported in the literature [18]. Mafu et al. [19] studied the adhesion of different bacteria to hydrophobic and hydrophilic surfaces in cultures at different $\mathrm{pH}(6,7$, and 8) and observed that this variable influenced the adhesion of some bacteria in the material surface.

The net charge of the yeast surface, which could be positive or negative, also depends on $\mathrm{pH}$. For Y. lipolytica W29, Aguedo et al. [20] reported that the isoelectric point occurs at $\mathrm{pH} 2.5$; below this value the net surface charge will be positive and above it will be negative. 


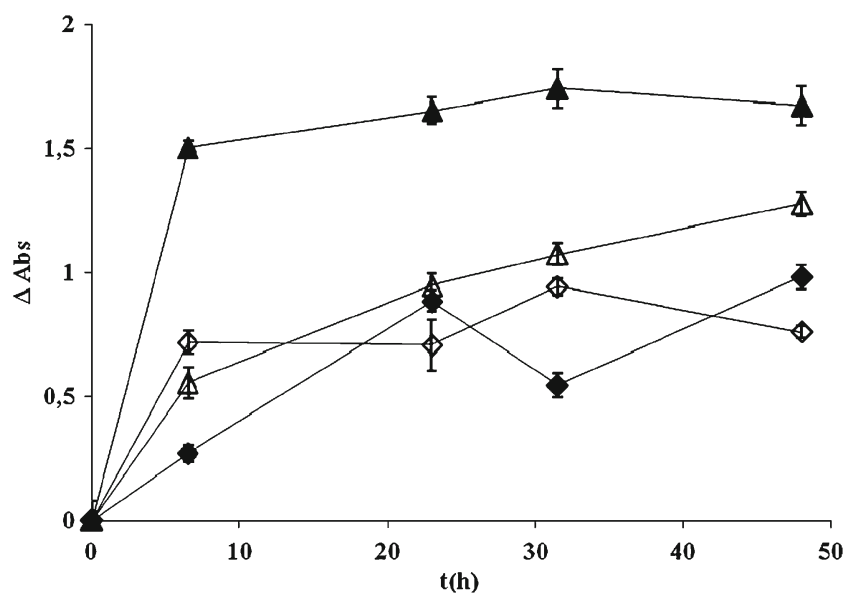

Fig. 1 Influence of the contact time, $\mathrm{pH}$ and total support area in the adhesion of $Y$. lipolytica onto PMMA cylinders: $\mathrm{pH} 9$ and $5.34 \mathrm{~m}^{2}$ support (filled triangles), $\mathrm{pH} 7$ and $3.56 \mathrm{~m}^{2}$ support (empty diamonds), $\mathrm{pH} 7$ and $5.34 \mathrm{~m}^{2}$ support (empty triangles), and $\mathrm{pH} 9$ and $3.56 \mathrm{~m}^{2}$ support (filled diamonds). Data are presented as the mean and standard deviation of two independent experiments

At the $\mathrm{pH}$ values investigated in this work (7 and 9), the surface of the cells is negatively charged and as the $\mathrm{pH}$ of the medium increases, the negative charge density of the yeast surface increases because of higher deprotonation of carboxyl, phosphate, and amine groups which result in a decreased electrostatic repulsion between the yeast cells and the support, which in turn, has a positive charge, favoring the adhesion phenomenon [21]. At $\mathrm{pH} 7$, the repulsive forces due to the net negative charge, start to have a lower impact on the adhesion process, resulting in a decreased number of adhered cells.

The results presented also shown that the number of adhered cells was dependent on the contact time between the support and the cells. The adhesion of yeast cells increased linearly with time for $10 \mathrm{~h}$ and after that, in general, the number of adhered yeast cells reached a saturation value. Time course led to an increase in the number of cells collisions with the support surface, and hence, an increase in opportunities for attachment [22, 23].

Also, it is possible to observe that the adhesion process was influenced by the total support area. A greater adhesion was obtained in the experiments performed with higher surface area $\left(5.34 \mathrm{~m}^{2}\right)$. In these conditions, more surface area was available for cell attachment and the free cells that remaining in the medium can adhere to the support. In these conditions, the adhesion phenomenon was controlled by the surface of the support.

To confirm the adhesion of cells onto PMMA surface, SEM observations were carried out and micrographs of the support surface and $Y$. lipolytica cells adhered onto the support are shown in Fig. 2. Cells were attached as single cells.

The main advantage of the immobilized systems is the obtainment of a high cell density without washout conditions. In order to increase the surface area for cell adhesion, more experiments were performed using DupUM ${ }^{\circledR}$ as support for cell immobilization since this new support present a design with high specific area for cell adhesion. The experiments were carried out at $\mathrm{pH} 9$ and $140 \mathrm{rpm}$ (best conditions previously described for cells adhesion on PMMA).

Figure 3 shows a dependence of cells adhesion to the support upon the initial cell concentration. Works described in literature demonstrate that the dependence of the 

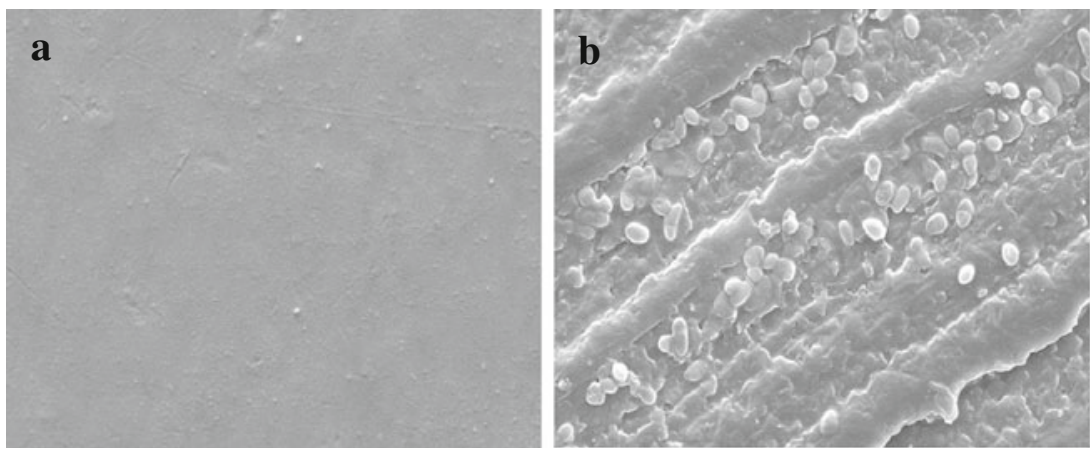

Fig. 2 Micrographs by scanning electron microscopy of the PMMA cylinders used for cells immobilization. Support surface (a) and after (b) the cells immobilization. Magnification, 1,000-fold

number of adherent yeast cells upon the initial biomass concentration has a linear behavior [10, 21-24]. The correlation between cell concentration and the number of adherent cells was analogous to an adsorption isotherm that represents the number of molecules adsorbed per surface unit as a function of concentration. When the initial biomass concentration is lower than the critical concentration, the adhesion may be controlled by the transport rate of the suspended cells from the liquid phase to the support surface. However, once this critical concentration is exceeded, the available adhesion surface of the support probably becomes the adhesion-limiting factor rather than the external mass transport. In addition, it has been reported that cells adhesion is strongly dependent on the available surface for cell adhesion [10, 25]. Also, an increase in concentration or time led to an increase in the number of yeast collisions with the surface, and hence, an increase in opportunities for attachment [22, 23].

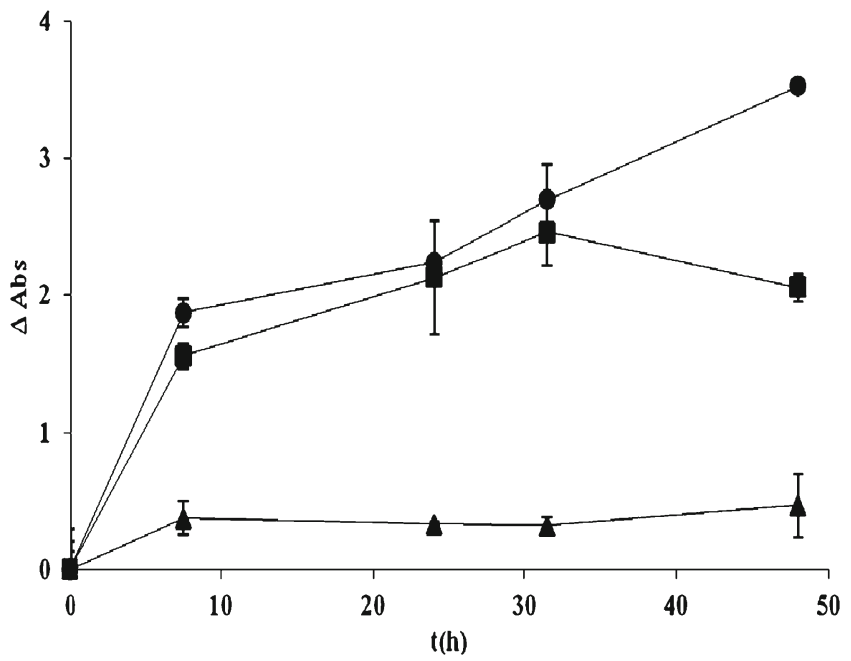

Fig. 3 Effect of initial cell concentration in adhesion of $Y$. lipolytica into DupUM ${ }^{\circledR}: 7.7 \times 10^{7}$ (triangles), $3.97 \times 10^{8}$ (squares), and $5.97 \times 10^{8}$ cells $\mathrm{mL}^{-1}$ (circles). Data are presented as the mean and standard deviation of two independent experiments 
We can observe that with a $0.7-$ and $0.9-\log$ increase in the initial cell concentration, a 5.4- and 4.6-fold increase in the cells adhesion was achieved. Since this support presents a high surface area, the increase of the initial cell concentration results in an increase of cellular adhesion once there are still available free areas on the support surface. Nevertheless, for cell concentrations of $3.97 \times 10^{8}$ and $5.97 \times 10^{8}$ cell mL $^{-1}$, a similar amount of adhered cells was obtained, since the surface for cell adhesion was completely cover with cells and was no free surface for cells adhesion. Also, the adsorption profiles in these conditions were very similar indicating that the surface of the support becomes thus the adhesion-limiting factor.

Moreover, an increase of 3.3-fold in the number of adhered cells per surface area was achieved in these experiments when compared with the assays performed with PMMA cylinders (for the best results obtained in each experiment).

The microscopic observation of the support surface revealed that the highest amount of adhered cells was obtained with an initial cell concentration of $5.97 \times 10^{8}$ cells mL $\mathrm{mL}^{-1}$ (Fig. 4b). The yeast cells covered the support surface in a thick layer, allowing a greater immobilization with this support.

The high specific contact area achieved with the particular shape of the Dup UM ${ }^{\circledR}$ support (Table 1) enabled a greater amount of cells adsorption compared with PMMA cylinders. This phenomenon has also been reported in other immobilization studies [26-28].

In order to better understand the phenomenon of cell adhesion, the relative surface hydrophobicity of the cells was evaluated at different stages of the adhesion process. Several methods have been described in the literature (the binding to hydrocarbons, salt aggregation test, adhesion to hydrophobic solid surfaces) [29], but the MATH assay is the most practical [30].

In the MATH test, $33.6 \pm 0.3 \%$ of cells, from the overall samples, adhered to hexadecane, after the change of the $\mathrm{pH}$ of the medium to 9 (results represent an average of three independent experiments \pm standard error). These results indicate that around $30 \%$ of the cells present in the medium have a hydrophobic surface and $70 \%$ are hydrophilic.

The value of the water contact angle can give preliminary information on the hydrophobicity of the support. For both supports investigated, the contact angle between water and support was $>50^{\circ}$ and $<80^{\circ}$, indicating that the support surface were hydrophilic [31]. The results obtained showed that this characteristic of the supports facilitated the adhesion of $Y$. lipolytica cells that are majority hydrophilic as shown by MATH test.
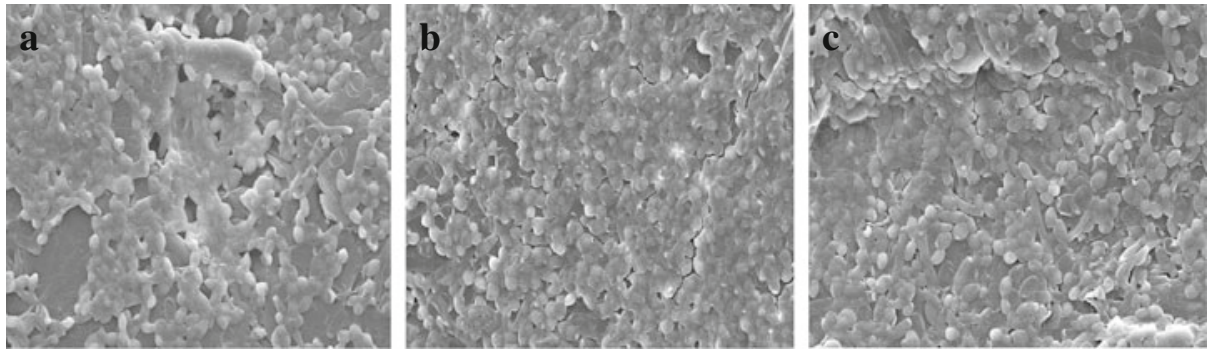

Fig. 4 Scanning electron micrographs of $Y$. lipolytica cells adhering to DupUM ${ }^{\circledR}$. Initial cells concentration, $7.7 \times 10^{7}(\mathbf{a}), 3.97 \times 10^{8}(\mathbf{b})$, and $5.97 \times 10^{8}$ cells $\mathrm{mL}^{-1}(\mathbf{c})$. Magnification, 1,000-fold 


\section{Biotransformation}

After selecting the best conditions for cell immobilization, biotransformations were carried out with immobilized cells in both supports and with free cells. The maximum aroma production of $1,597 \pm 34 \mathrm{mgL}^{-1}$ (corresponding to a molar conversion of $29 \%$ ) was obtained with cells adsorbed on DupUM ${ }^{\circledR}$ after $264 \mathrm{~h}$. In the experiments with free cells, a concentration of $954 \pm$ $7 \mathrm{mgL}^{-1} \gamma$-decalactone was obtained in $120 \mathrm{~h}$. The maximum aroma concentration obtained in these conditions is lower than other reported values [2] since these studies were performed with improved strains. Thus the immobilization studies herein presented can have potential application with those strains.

In the experiment with free cells, the production of $\gamma$-decalactone increases up to a maximum value after which decreases, until complete disappearance from the medium. This decrease in $\gamma$-decalactone production is due to the fact that this metabolite is consumed by yeasts as a carbon source or is resumed and used for the production of other products of the $\beta$-oxidation pathway [13]. Nevertheless, this behavior was not observed with immobilized cells and the aroma concentration was maintained in the biotransformation medium during the whole experiment. This may be related with the fact that in the experiments with immobilized cells, $\gamma$-decalactone are not so accessible to immobilized cells, thus its reconsumption is slower than with free cells. Moreover, immobilized cells are protected from the inhibitory effect of the $\gamma$ decalactone concentration in the bulk medium. This is a great advantage of using immobilized cells when compared with free cells, since, in these conditions, the aroma is not consumed and the subsequent recovery and purification process is easier.

Thus, the best approach to increase $\gamma$-decalactone production, from hydrolyzed castor oil, is to adsorb Y. lipolytica cells on DupUM ${ }^{\circledR}$ (Fig. 5), since a greater amount of $\gamma$-decalactone was obtained and the aroma remained in the medium.

The highest productivity of the process was obtained with free cells $\left(7 \pm 1 \mathrm{mgL}^{-1} \mathrm{~h}^{-1}\right)$, but the maximum aroma concentration was obtained with adsorbed cells in DupUM ${ }^{\circledR}$, that have important impact on the further extraction and purification of the aroma. Also, this is a very promising result for $\gamma$-decalactone production, with potential to be used at an industrial level since the use of immobilized cells system will facilitate the conversion

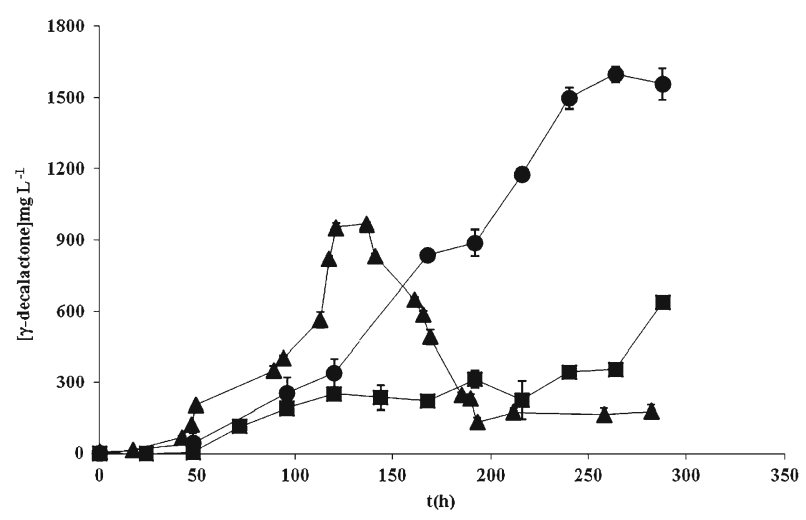

Fig. $5 \gamma$-decalactone production with hydrolyzed castor oil with free (triangles) and immobilized cells: PMMA cylinders (squares) and DupUM ${ }^{\mathbb{B}}$ (circles). Data are presented as the mean and standard deviation of two independent experiments 
of a batch process into a continuous mode keeping high cell density and allowing easier recovery of metabolic products.

\section{Conclusions}

As far as our knowledge goes, this is the first report on the production of $\gamma$-decalactone from castor oil by adsorbed Y. lipolytica cells into new proposed supports such as DupUM ${ }^{\circledR}$. The results obtained showed that immobilization protects the microbial cells against the possible toxic effect of substrates or products. The results are very promising and present great potential for producing the aroma at industrial level since the aroma is not consumed during the process using immobilized cells, as opposed to what occurs using free cells. Moreover, the implementation of a continuous aroma production process could be achieved based on the results here presented.

Acknowledgments The authors acknowledge Fundação para a Ciência e Tecnologia (FCT) for the financial support provided (SFRH/BD/63701/2009).

\section{References}

1. Siek, T. J., Albin, I. A., Sather, L. A., \& Lindsay, R. C. (1971). Journal of Dairy Science, 54, 1-9.

2. Schrader, J., Etschmann, M. M. W., Sell, D., Hilmer, J.-M., \& Rabenhorst, J. (2004). Biotechnology Letters, 26, 463-472.

3. Pagot, Y., Le Clainche, A., Nicaud, J.-M., Waché, Y., \& Belin, J.-M. (1998). Applied Microbiology and Biotechnology, 49, 295-300.

4. Waché, Y., Aguedo, M., Nicaud, J.-M., \& Belin, J.-M. (2003). Applied Microbiology and Biotechnology, 61, 393-404.

5. Aguedo, M., Beney, L., Waché, Y., \& Belin, J.-M. (2009). Journal of Applied Microbiology, 94, $258-265$.

6. Lee, S. L., Cheng, H. Y., Chen, W. C., \& Chou, C. C. (1998). Process Biochemistry, 33, 453-459.

7. Neto, R. S., Pastore, G. M., \& Macedo, G. A. (2004). Journal of Food Science, 69, 677-680.

8. Lin, S. J., Lee, S. L., \& Chou, C. C. (1996). Journal of Fermentation and Bioengineering, 82, $42-45$.

9. Matos, M., Alves, C., Campos, J. L., Brito, A. G., \& Nogueira, R. (2011). Environmental Technology, 32, 1121-1129.

10. Rochex, A., Lecouturier, D., Pezron, I., \& Lebeault, J. M. (2004). Applied Microbiology and Biotechnology, 65, 727-733.

11. Aguedo, M., Waché, Y., Mazoyer, V., Sequeira-LeGrand, A., \& Belin, J.-M. (2003). Journal of Agricultural and Food Chemistry, 51, 3007-3011.

12. Gonçalves, C., Rodriguez-Jasso, R. M., Gomes, N., Teixeira, J. A., \& Belo, I. (2010). Analytical Methods, 2, 2046-2048.

13. Gomes, N., Braga, A., Teixeira, J, \& Belo, I. (2013). J. Am. Oil Chem. Soc (in press).

14. Kwok, D. Y., \& Neumann, A. W. (1999). Advances in Colloid and Interface Science, 81, 167-249.

15. Gomes, N., Teixeira, J. A., \& Belo, I. (2010). Biocatal Biotransform, 28, 227-234.

16. Kolot, F. B. (1981). Process Biochemistry, 16, 2-9.

17. Czaczyk, K., \& Myszka, K. (2007). Polish Journal of Environmental Studies, 16, 799-806.

18. Klein, J., \& Ziehr, H. (1990). Journal of Biotechnology, 16, 1-15.

19. Mafu, A. K., Plumety, C., Deschênes, L. \& Goulet, J. (2011) International Journal of Microbiology doi:10.1155/2011/972494.

20. Aguedo, M., Gomes, N., Escamilla-Garcia, E., Waché, Y., Mota, M., Teixeira, J. A., et al. (2005). Biotechnology Letters, 27, 1617-1621.

21. Liu, Y. (1995). Colloids and Surfaces B, 5, 213.

22. Fletcher, M. (1977). Canadian Journal of Microbiology, 23, 1-6.

23. Bellon-Fontaine, M. N., \& Cerf, O. (1991). Industrial Agricultural Alignment, 108, 13-17.

24. Bryers, J., \& Characklis, W. (1981). Water Research, 15, 191-483. 
25. Belkhadir, R. (1986), Ph.D. thesis, Institut National des Sciences Appliques de Toulouse.

26. Brányik, T., Vicente, A. A., Oliveira, R., \& Teixeira, J. A. (2004). Biotechnology and Bioengineering, 88, 84-93.

27. Kosaric, N., \& Blaszczyk, R. (1990). Wastewater treatment by immobilized cells. Boca Raton: CRC Press.

28. Yu, J., Yue, G., Zhong, J., Zhang, X., \& Tan, T. (2010). Renewable Energy, 35, 1130-1134.

29. Doyle, R.J. \& Rosenberg, M. (1990). Washington, DC: American Society for Microbiology

30. Capizzi, S., \& Schwartzbrod, J. (2001). Colloids and Surfaces B, 22, 99-105.

31. Zgura, I., Beica, T., Mitrofan, I. L., Mateias, C. G., Pirvu, D., \& Patrascu, I. (2010). Digestive Journal Nanomater Biosciences, 5, 749-755. 